\title{
Synthesis of Novel $E$-2-Chlorovinyltellurium Compounds Based on the Stereospecific Anti-addition of Tellurium Tetrachloride to Acetylene
}

\section{Maria V. Musalova, Vladimir A. Potapov * and Svetlana V. Amosova *}

A. E. Favorsky Irkutsk Institute of Chemistry, Siberian Branch of the Russian Academy of Sciences, 1 Favorsky Str., Irkutsk 664033, Russia

* Authors to whom correspondence should be addressed; E-Mails: v_a_potapov@irioch.irk.ru (V.A.P.); amosova@irioch.irk.ru (S.V.A.); Tel.: +7-395-2424-954 (V.A.P.); Fax: +7-395-2419-346 (S.V.A.).

Received: 5 April 2012; in revised form: 6 May 2012 / Accepted: 8 May 2012 /

Published: 15 May 2012

\begin{abstract}
The reaction of tellurium tetrachloride with acetylene proceeds in a stereospecific anti-addition manner to afford the novel products $E$-2-chlorovinyltellurium trichloride and E,E-bis(2-chlorovinyl)tellurium dichloride. Reaction conditions for the selective preparation of each of these products were found. The latter was obtained in $90 \%$ yield in $\mathrm{CHCl}_{3}$ under a pressure of acetylene of 10-15 atm, whereas the former product was formed in up to $72 \%$ yield in $\mathrm{CCl}_{4}$ under a pressure of acetylene of 1-3 atm. Synthesis of the previously unknown E,E-bis(2-chlorovinyl) telluride, E,E-bis(2-chlorovinyl) ditelluride, E-2-chlorovinyl 1,2,2-trichloroethyl telluride and E,E-bis(2-chlorovinyl)tellurium dibromide is described.
\end{abstract}

Keywords: acetylene; tellurium tetrachloride; anti-addition; chlorovinyl tellurides; chlorovinyltellurium trichlorides; bis(2-chlorovinyl)tellurium dichlorides; divinyl ditellurides

\section{Introduction}

Selenium was considered a poison for many years, until Schwarz and Foltz identified it as an essential micronutrient for mammals, including human beings [1]. Like selenium, tellurium was regarded a poison for many years until non-toxic organotellurium compounds with high biological activity were found [2-8]. Like organoselenium compounds, a number of organotellurium compounds exhibit high glutathione peroxidase-like activity [2-5]. A four-valent tellurium compound, ammonium 
trichloro(dioxoethylene-O, $\mathrm{O}^{\prime}$-)tellurate, also known as AS-101, possesses high immunomodulating activity [2,3,6-8]. When administered to mice, this compound mediates antitumor effects and protects mice from ionizing radiation $[2,3,6]$. The tests demonstrated that AS-101 is potentially useful in the treatment of clinical immunosuppression conditions involving cancer and AIDS $[2,3,6]$. The literature [2-8] indicates that among organotellurium compounds, mainly telluranes (four-valent tellurium compounds), exhibit high biological activity.

The principal electrophilic tellurium-containing reagent is tellurium tetrachloride. The first example of the addition of $\mathrm{TeCl}_{4}$ to acetylenes was reported in 1962 [9]. The reaction of $\mathrm{TeCl}_{4}$ with phenylacetylene and diphenylacetylene afforded the corresponding 2-chlorovinyltellurium trichlorides, however, the stereochemistry of the products was not determined [9]. It has been shown later that the reactions of $\mathrm{TeCl}_{4}$ with phenylacetylene, diphenylacetylene and alkylphenylacetylenes proceed in highly regiospecific and stereospecific manner via syn-addition to afford the products of $Z$-stereochemistry [10-15]. The Z-configuration was confirmed by X-ray analysis [15]. A special case is the addition of tellurium tetrachloride to acetylenic alcohols $[13,16]$, since the hydroxy group influences the stereochemistry [13].

Nowadays, the distinguishing property of tellurium reagents to react with high regio- and stereoselectivity finds increasing application in organic synthesis [17-19]. The adducts of $\mathrm{TeCl}_{4}$ with acetylenes were recognized as important precursors and synthons for organic synthesis and applied in many approaches for the preparation of various functionalized alkenes in a highly regio- and stereospecific manner [17-19]. The reduction of bisadducts of $\mathrm{TeCl}_{4}$ with acetylenes gives 2-chloro-vinyltellurides, which are used for preparation of various useful products by metallation and cross-coupling reactions [11,17-19].

A mechanism with the formation of 4-membered transition state $\mathbf{A}$ was proposed in order to explain stereospecific syn-addition of tellurium tetrachloride to the triple bond of alkynes (Scheme 1) [14,20].

Scheme 1. The mechanism of stereospecific syn-addition of $\mathrm{TeCl}_{4}$ to alkynes.

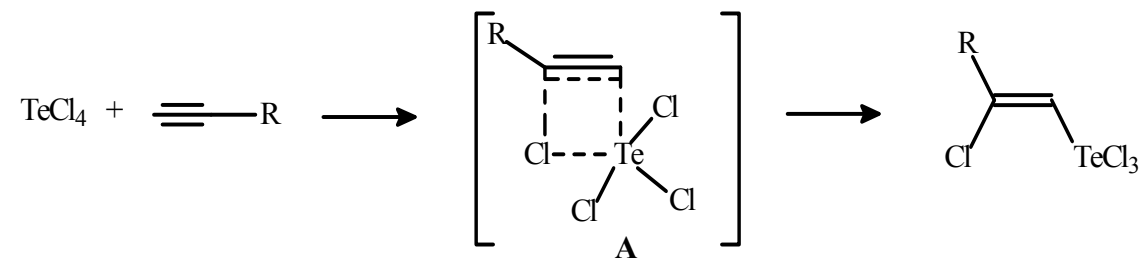

It is worth noting that compounds with high biological (antioxidative and antimetastatic) activity were found among the adducts of $\mathrm{TeCl}_{4}$ with acetylenes [3]. Therefore, studies of previously unknown reactions of tellurium tetrachloride with acetylenes with the goal to obtain novel organotellurium (IV) compounds and to investigate their properties is an important task for organic chemists.

Synthesis of unsaturated tellurides and studies of their properties is the subject of our continued interest [21-30]. Earlier we elaborated efficient methods for the preparation of vinylic tellurides by nucleophilic addition of telluride and organotellurolate anions to acetylene [31-35] and phenylacetylene [36-38]. Addition of tellurium tetrachloride to trimethylethynyl silane and diorganyldiethynyl silanes led to novel unsaturated tellurium-silicon containing compounds [39,40]. The present paper describes electrophilic addition of tellurium tetrachloride to acetylene. 
Acetylene is a versatile multi-thousand ton chemical feedstock and many its reactions are of high value from both theoretical and practical viewpoints. In view of the rapid depletion of hydrocarbon resources, acetylene, which can be alternatively manufactured from coal, is expected to acquire an increasingly more important role as a universal chemical starting material [41]. Reactions of inorganic compounds with acetylene by convenient procedures giving high yields of target products may find useful applications, not only in organic synthesis, but in industry as well.

\section{Results and Discussion}

There were no data in the literature concerning reactions of tellurium halides with unsubstituted acetylene prior to our research. In a letter [42] we briefly reported our preliminary results on studies of the reaction of tellurium tetrachloride with acetylene and the formation of a bisadduct, the previously unknown E,E-bis(2-chlorovinyl)tellurium dichloride (1), in $62 \%$ yield. The present paper is the complete account of our studies of this reaction under various reaction conditions.

We have found that the performance of the reaction of tellurium tetrachloride with acetylene in carbon tetrachloride at room temperature under atmospheric pressure allows one to obtain a monoadduct, the previously unknown $E$-(2-chlorovinyl)tellurium trichloride (2) (Scheme 2).

Scheme 2. Reactions of $\mathrm{TeCl}_{4}$ with acetylene under atmospheric pressure.
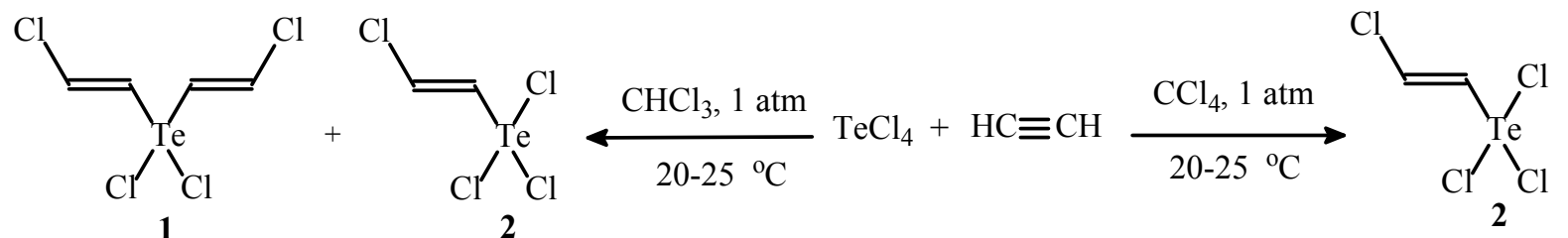

In carbon tetrachloride, the reaction proceeded chemo- and stereoselectively via anti-addition to give only monoadduct $\mathbf{2}$ and the formation of bisadduct $\mathbf{1}$ was not observed. When acetylene was bubbled into the reaction mixture at room temperature during $2 \mathrm{~h}$, the yield of monoadduct 2 was $30 \%$ (with incomplete conversion of tellurium tetrachloride). Increasing the duration of the reaction from 2 to $5 \mathrm{~h}$ raised the conversion of tellurium tetrachloride, but led to the formation of some by-products.

Monoadduct $\mathbf{2}$ is also formed when the reaction was carried out in chloroform at room temperature under atmospheric pressure, but compound 2 was converted into bisadduct $\mathbf{1}$ ( $82 \%$ yield) under these conditions (Scheme 2). The selective formation of compound 2 was observed in the initial period of the reaction in chloroform $\left({ }^{1} \mathrm{H}-\mathrm{NMR}\right.$ monitoring of the reaction carried out in $\left.\mathrm{CDCl}_{3}\right)$; then bisadduct 1 appeared and its content increased over time and, consequently, the concentration of monoadduct 2 decreased in time and, finally, disappeared by the end of the reaction.

Performing the reaction of tellurium tetrachloride with acetylene in carbon tetrachloride at a temperature of $10-20{ }^{\circ} \mathrm{C}$ under a pressure of acetylene of $2-3 \mathrm{~atm}$ in an autoclave allowed us to increase the conversion of $\mathrm{TeCl}_{4}$ and to obtain compound $\mathbf{2}$ in $72 \%$ yield.

The highest yield of bisadduct 1 was achieved when the reaction of tellurium tetrachloride with acetylene was carried out in an autoclave under a higher pressure of acetylene (12-15 atm) in dry chloroform at $20-40{ }^{\circ} \mathrm{C}$ for $5 \mathrm{~h}$ (Scheme 3). The reaction proceeds in a stereospecific manner via anti-addition to afford the product 1 in $94 \%$ yield. 
Scheme 3. Reactions of $\mathrm{TeCl}_{4}$ with acetylene under the pressure in an autoclave.

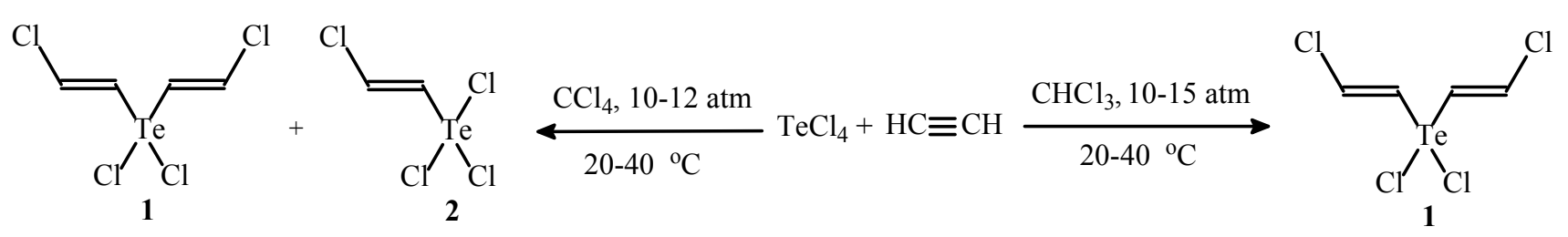

When the reaction of tellurium tetrachloride with acetylene was carried out in carbon tetrachloride under a pressure of acetylene of 10-12 atm at room temperature in an autoclave, the formation of both products 1 and 2 in 78\% and 17\% yields, respectively, was observed (Scheme 3). Increasing the pressure of acetylene to $14-15 \mathrm{~atm}$ and the reaction temperature to $30-40{ }^{\circ} \mathrm{C}$ permitted us to selectively obtain bisadduct 1 in $90 \%$ yield.

Thus, in contrast to the $s y n$-addition of tellurium tetrachloride to substituted acetylenes [9-15], the reaction of tellurium tetrachloride with acetylene proceeds as an anti-addition to give the products $\mathbf{1}$ and $\mathbf{2}$ of $E$-stereochemistry. This is the first example of the anti-addition of tellurium tetrachloride to acetylenic hydrocarbons. The formation of the 3-membered intermediates $\mathbf{B}$ and $\mathbf{C}$ was supposed to explain the stereospecific anti-addition (Scheme 4).

Scheme 4. The supposed mechanism of the anti-addition of $\mathrm{TeCl}_{4}$ to acetylene.

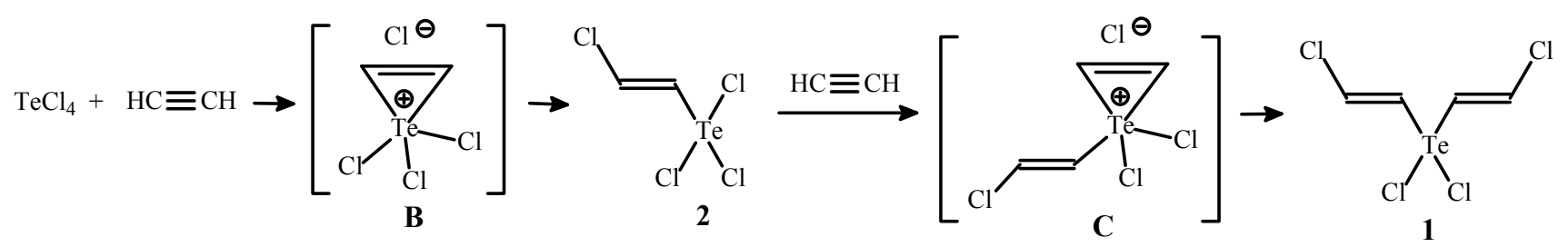

We presume that in the case of acetylene, the 3-membered intermediates (B and $\mathbf{C}$, Scheme 4) are energetically preferred in comparison with a possible 4-membered transition state $\mathbf{A}$ (Scheme 1). It is noteworthy that the formation of similar 3-membered intermediates is well known for the addition of organic sulfenyl and selenenyl halides (RSHal, RSeHal) to alkynes [43].

When the reaction was carried out in benzene under similar conditions $\left(25-40{ }^{\circ} \mathrm{C}\right.$, autoclave, pressure of acetylene of 10-15 atm), the formation of E-2-chlorovinyl 1,2,2-trichloroethyl telluride (3) in $10-15 \%$ yield was observed, along with the main product 1 ( $70-82 \%$ yield) (Scheme 5).

Scheme 5. The reaction of $\mathrm{TeCl}_{4}$ with acetylene in benzene.

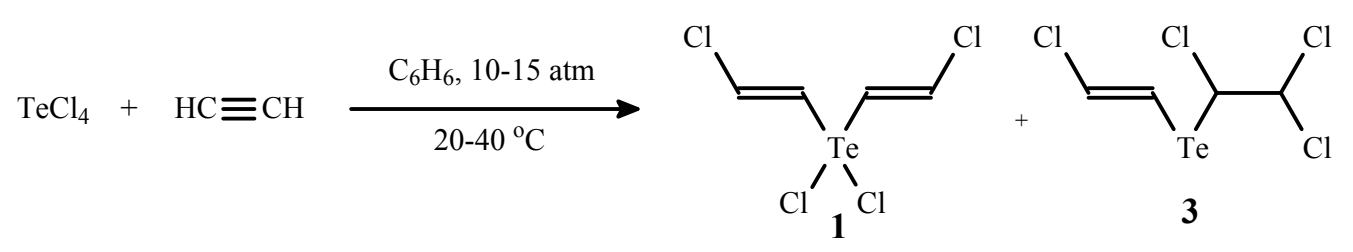

It would be logical to suppose that the formation of $\mathbf{3}$ is the result of rearrangement of chlorine atoms in compound $\mathbf{1}$. However, heating bisadduct $\mathbf{1}$ in benzene at $40{ }^{\circ} \mathrm{C}$ did not give compound 3 .

Previously unknown E,E-bis(2-chlorovinyl) ditelluride (4) was obtained in $64 \%$ yield by the reduction of compound 2 with aqueous solution of $\mathrm{Na}_{2} \mathrm{~S}_{2} \mathrm{O}_{5}$ (Scheme 6). 
Scheme 6. The synthesis of ditelluride 4 by reduction of compound 2.
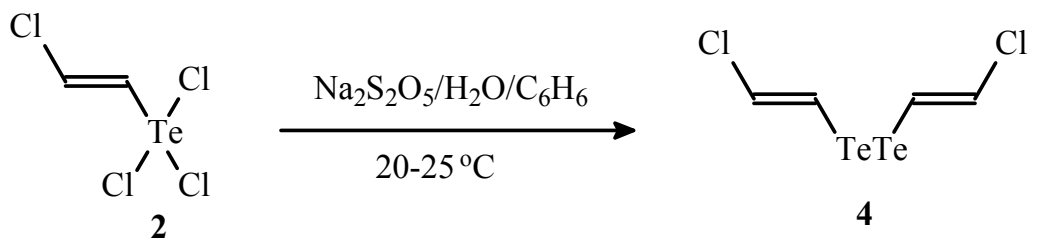

Organic ditellurides constitute an important class of organotellurium compounds, which are used for generation of highly nucleophilic organyltellurolate anions by reduction of the Te-Te bond as well as for preparation of electrophilic reagents $\mathrm{RTeHal}$ and $\mathrm{RTeHal}$ by halogenations $\left(\mathrm{SO}_{2} \mathrm{Cl}_{2}, \mathrm{Br}_{2}\right)$ of organic ditellurides [17-19]. Compound 4 can find application as a starting material for the synthesis of novel compounds bearing an E-2-chlorovinyltellanyl moiety. It is noteworthy that data on synthesis of divinyl ditellurides are very scarce in the literature [44-46].

In a similar manner, bisadduct 1 was reduced to previously unknown $E$,E-bis(2-chlorovinyl) telluride (5) in $86 \%$ yield (Scheme 7).

Scheme 7. The synthesis of telluride 5 by reduction of compound 1 .
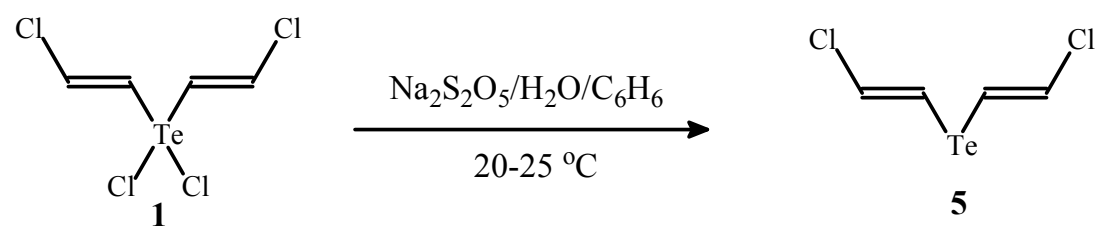

It is known that 2-halovinyltellurides are used for the preparation of valuable products by cross-coupling reactions [17-19] and therefore telluride 5 may be useful for stereoselective synthesis of functionalized alkenes. The reaction of telluride $\mathbf{5}$ with bromine afforded tellurane $\mathbf{6}$ containing different halogen atoms in one molecule (Scheme 8).

Scheme 8. The synthesis of tellurane 6 by the reaction of telluride 5 with bromine.

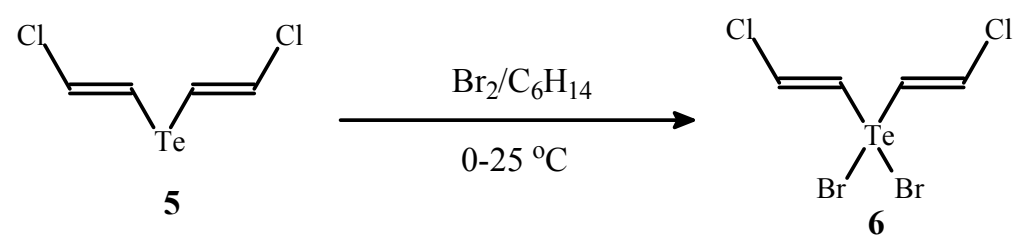

\section{Experimental}

\subsection{General Information}

${ }^{1} \mathrm{H}(400.1 \mathrm{MHz})$ and ${ }^{13} \mathrm{C}(100.6 \mathrm{MHz})$ spectra were recorded on a Bruker DPX-400 spectrometer (Karlsruhe, Germany) in DMSO- $d_{6}$, or $\mathrm{CDCl}_{3}$ (HMDS). Mass spectra were recorded on a Shimadzu GCMS-QP5050A spectrometer (Duisburg, Germany). Tellurium tetrachloride was prepared from tellurium and sulfuryl chloride [12]. 


\subsection{Synthetic Procedures for the Preparation of Compounds 1-6}

E,E-Bis(2-chlorovinyl)tellurium dichloride (1). A mixture of $\mathrm{TeCl}_{4}(2.69 \mathrm{~g}, 10 \mathrm{mmol})$ and dry chloroform $(100 \mathrm{~mL})$ was heated $\left(30-40{ }^{\circ} \mathrm{C}\right)$ in a $1 \mathrm{~L}$ rotating autoclave under acetylene pressure (12-14 atm) for $5 \mathrm{~h}$. The solvent was evaporated and the residue was washed with cold hexane and dried to give compound 1 (3.03 g, 94\% yield) as a colorless powder, m.p. $112-113{ }^{\circ} \mathrm{C}$. Found (\%): C, 15.24; H, 1.17; Cl, 43.89. $\mathrm{C}_{4} \mathrm{H}_{4} \mathrm{Cl}_{4}$ Te. Calculated (\%): C, 14.94; $\mathrm{H}, 1.25 ; \mathrm{Cl}, 44.11 .{ }^{1} \mathrm{H}-\mathrm{NMR}$ (DMSO- $d_{6}$, $\delta$, ppm): 7.25 (d, $2 \mathrm{H}, J=13.9 \mathrm{~Hz}), 7.48(\mathrm{~d}, 2 \mathrm{H}, J=13.9 \mathrm{~Hz}) .{ }^{13} \mathrm{C}-\mathrm{NMR}$ (DMSO- $\left.d_{6}, \delta, \mathrm{ppm}\right): 129.80$ $(\mathrm{TeCH}), 133.34(\mathrm{CHCl}) . \mathrm{MS}(70 \mathrm{eV}), \mathrm{m} / z\left(I_{\text {rel. }}, \%\right): 287(100)[\mathrm{M}-\mathrm{Cl}]^{+}, 252(48)[\mathrm{M}-2 \mathrm{Cl}]^{+}, 226(71)$ $[\mathrm{ClTeCH}=\mathrm{CHCl}]^{+}, 200(12)[\mathrm{TeCl} 2]^{+}, 191(28)[\mathrm{TeCH}=\mathrm{CHCl}]^{+}, 165(66)[\mathrm{TeCl}]^{+}, 130$ (52) $[\mathrm{Te}]^{+}, 122$ (82) $\left[\mathrm{C}_{4} \mathrm{H}_{4} \mathrm{Cl}_{2}\right]^{+}, 87(86)\left[\mathrm{C}_{4} \mathrm{H}_{4} \mathrm{Cl}\right]^{+}, 61(37)\left[\mathrm{C}_{2} \mathrm{H}_{2} \mathrm{Cl}\right]^{+}, 51(70)\left[\mathrm{C}_{4} \mathrm{H}_{3}\right]^{+}, 36(52)[\mathrm{HCl}]^{+}, 26(80)$ $\left[\mathrm{C}_{2} \mathrm{H}_{2}\right]^{+}$.

E-(2-Chlorovinyl)tellurium trichloride (2). Dry $\mathrm{CCl}_{4}(50 \mathrm{~mL})$ was saturated with acetylene by bubbling dry acetylene for $1 \mathrm{~h}$ at atmospheric pressure. Then $\mathrm{TeCl}_{4}(0.54 \mathrm{~g}, 2 \mathrm{mmol})$ was added and dry acetylene was bubbled through the mixture with intensive stirring for $2 \mathrm{~h}$. The solution was decanted from the precipitate and new portion of dry $\mathrm{CCl}_{4}(50 \mathrm{~mL})$ was added to the precipitate and stirred for $1 \mathrm{~h}$. The solution was decanted from the precipitate and combined with the first portion of the $\mathrm{CCl}_{4}$ solution. After evaporation of the solvent, the residue was washed with cold hexane and dried to give product $2(0.18 \mathrm{~g}, 30 \%$ yield $)$ - Colorless powder, which upon heating begins to darken at 45-47 ${ }^{\circ} \mathrm{C}$ and then decomposed. Found (\%): C, 7.98; H, 0.78; Cl, 47.66. $\mathrm{C}_{2} \mathrm{H}_{2} \mathrm{Cl}_{4} \mathrm{Te}$. Calculated (\%): $\mathrm{C}, 8.13 ; \mathrm{H}, 0.68 ; \mathrm{Cl}, 48.00 .{ }^{1} \mathrm{H}-\mathrm{NMR}$ (DMSO- $\left.d_{6}, \delta, \mathrm{ppm}\right): 7.38(\mathrm{~d}, 2 \mathrm{H}, \mathrm{CHCl}, J=13.4 \mathrm{~Hz}$ ), 7.82 $(\mathrm{d}, 2 \mathrm{H}, \mathrm{TeCH}, J=13.4 \mathrm{~Hz}) .{ }^{13} \mathrm{C}-\mathrm{NMR}\left(\mathrm{DMSO}-d_{6}, \delta, \mathrm{ppm}\right): 131.32,145.67$.

E-2-Chlorovinyl 2,2,1-trichloroethyl telluride (3). A mixture of $\mathrm{TeCl}_{4}(2.69 \mathrm{~g}, 10 \mathrm{mmol})$ and benzene $(80 \mathrm{~mL})$ was heated $\left(20-40{ }^{\circ} \mathrm{C}\right)$ in a $1 \mathrm{~L}$ rotating autoclave under acetylene pressure $(12-14 \mathrm{~atm})$ for $5 \mathrm{~h}$. The solvent was evaporated and the residue was washed with cold hexane and dried to give compound 1 ( $2.25 \mathrm{~g}, 70 \%$ yield) as a colorless powder. The solvent was evaporated from the hexane solution and the residue was subjected to short column chromatography on silica gel (eluent hexane) to give compound 3 (0.48 g, 15\% yield) as a dark liquid. Found (\%): C, 14.58; H, 1.36; Cl, 44.45. $\mathrm{C}_{4} \mathrm{H}_{4} \mathrm{Cl}_{4}$ Te. Calculated (\%): C, 14.94; $\mathrm{H}, 1.25 ; \mathrm{Cl}, 44.11 .{ }^{1} \mathrm{H}-\mathrm{NMR}\left(\mathrm{CDCl}_{3}, \delta, \mathrm{ppm}\right): 5.32(\mathrm{~d}, 1 \mathrm{H}$, $J=3.3 \mathrm{~Hz}) ; 6.03(\mathrm{~d}, 1 \mathrm{H}, J=3.3 \mathrm{~Hz}), 6.66(\mathrm{~d}, 1 \mathrm{H}, J=13.3 \mathrm{~Hz}), 6.87(\mathrm{~d}, 1 \mathrm{H}, J=13.3 \mathrm{~Hz}) .{ }^{13} \mathrm{C}-\mathrm{NMR}$ $\left(\mathrm{CDCl}_{3}, \delta, \mathrm{ppm}\right): 62.89(\mathrm{TeCHCl}), 74.58\left(\mathrm{CHCl}_{2}\right) .116 .21(\mathrm{TeCH}=), 127.87(=\mathrm{CHCl})$.

E,E-Bis(2-chlorovinyl) ditelluride (4). A solution of $\mathrm{Na}_{2} \mathrm{~S}_{2} \mathrm{O}_{5}(0.95 \mathrm{~g}, 5 \mathrm{mmol})$ in water $(5 \mathrm{~mL})$ was added to a mixture of compound $2(0.15 \mathrm{~g}, 0.5 \mathrm{mmol})$ and benzene $(2 \mathrm{~mL})$. The resulted mixture was vigorously stirred at room temperature for $24 \mathrm{~h}$ under argon. The mixture was extracted with benzene $(3 \times 5 \mathrm{~mL})$, organic phase was dried, filtered and the solvent was evaporated. The residue was subjected to column chromatography (eluent-hexane) to give ditelluride 4 (60.8 $\mathrm{mg}, 64 \%$ yield) as a dark red oil. Found (\%): C, 13.08; H, 1.20; Cl, 19.06. $\mathrm{C}_{4} \mathrm{H}_{4} \mathrm{Cl}_{2} \mathrm{Te}_{2}$. Calculated (\%): $\mathrm{C}, 12.70 ; \mathrm{H}, 1.07$; $\mathrm{Cl}, 18.75 .{ }^{1} \mathrm{H}-\mathrm{NMR}\left(\mathrm{CDCl}_{3}, \delta, \mathrm{ppm}\right): 6.49$ (d, 2H, CHCl, $\left.J=13.6 \mathrm{~Hz}\right), 7.37$ (d, 2H, TeCH, $\left.J=13.6 \mathrm{~Hz}\right)$. ${ }^{13} \mathrm{C}-\mathrm{NMR}\left(\mathrm{CDCl}_{3}, \delta, \mathrm{ppm}\right): 93.28(\mathrm{TeCH}), 125.34(\mathrm{CHCl}) . \mathrm{MS}(70 \mathrm{eV}), \mathrm{m} / z\left(I_{\mathrm{rel} .}, \%\right): 380(64)[\mathrm{M}]^{+}$, 
319 (16) $\left[\mathrm{M}-\mathrm{C}_{2} \mathrm{H}_{2} \mathrm{Cl}\right]^{+}, 293$ (27) $\left[\mathrm{Te}_{2} \mathrm{Cl}\right]^{+}, 258(18)\left[\mathrm{Te}_{2}\right]^{+}, 252$ (47) $[\mathrm{M}-\mathrm{Te}]^{+}, 191(100)\left[\mathrm{TeC}_{2} \mathrm{H}_{2} \mathrm{Cl}\right]^{+}$, $165(88)\left[\mathrm{TeC}_{2} \mathrm{H}\right]^{+}, 130(80)[\mathrm{Te}]^{+}, 61(44)\left[\mathrm{C}_{2} \mathrm{H}_{2} \mathrm{Cl}\right]^{+}, 51(33)\left[\mathrm{C}_{4} \mathrm{H}_{3}\right]^{+}$.

E,E-Bis(2-chlorovinyl) telluride (5). A solution of $\mathrm{Na}_{2} \mathrm{~S}_{2} \mathrm{O}_{5}(0.95 \mathrm{~g}, 5 \mathrm{mmol})$ in water $(5 \mathrm{~mL})$ was added to a mixture of compound $1(0.16 \mathrm{~g}, 0.5 \mathrm{mmol})$ and benzene $(2 \mathrm{~mL})$. The resulting mixture was vigorously stirred at room temperature for $24 \mathrm{~h}$ under argon. The mixture was extracted with benzene $(3 \times 5 \mathrm{~mL})$, the organic phase was dried, filtered and the solvent was evaporated. The residue was subjected to column chromatography (eluent-hexane) to give telluride $\mathbf{5}(108 \mathrm{mg}, 86 \%$ yield) as a dark yellow oil. Found (\%): C, 18.94; H, 1.75; Cl, 28.68. $\mathrm{C}_{4} \mathrm{H}_{4} \mathrm{Cl}_{2}$ Te. Calculated (\%): C, 19.17; H, 1.61; Cl, 28.30. ${ }^{1} \mathrm{H}-\mathrm{NMR}\left(\mathrm{CDCl}_{3}, \delta, \mathrm{ppm}\right): 6.34$ (d, 2H, CHCl, $\left.J=14.0 \mathrm{~Hz}\right), 6.89$ (d, 2H, TeCH, $\left.J=14.0 \mathrm{~Hz}\right)$. ${ }^{13} \mathrm{C}-\mathrm{NMR}\left(\mathrm{CDCl}_{3}, \delta, \mathrm{ppm}\right): 100.02(\mathrm{TeCH}), 128.14(\mathrm{CHCl})$.

E,E-Bis(2-chlorovinyl)tellurium dibromide (6). A solution of bromine (320 $\mathrm{mg}, 2 \mathrm{mmol})$ in hexane (2 $\mathrm{mL})$ was added dropwise to a stirred solution of compound $5(501 \mathrm{mg}, 2 \mathrm{mmol})$ in hexane $(5 \mathrm{~mL})$ at $0{ }^{\circ} \mathrm{C}$ (an ace bath). The mixture was stirred for $1 \mathrm{~h}$ at $0{ }^{\circ} \mathrm{C}$ and for $1 \mathrm{~h}$ at room temperature. The solvents were decanted and the precipitate was washed with cold hexane and dried under vacuum to give compound 6 (755 mg, 92\% yield) as a brown powder, m.p. 265-268 ${ }^{\circ} \mathrm{C}$. Found (\%): C, 11.46; H, 1.08; $\mathrm{Cl}, 16.97 ; \mathrm{Br}, 39.23 . \mathrm{C}_{4} \mathrm{H}_{4} \mathrm{Cl}_{2} \mathrm{Br}_{2}$ Te. Calculated (\%): C, 11.71; H, 0.98; Cl, 17.28; Br, 38.94. ${ }^{1} \mathrm{H}-\mathrm{NMR}$ (DMSO- $\left.d_{6}, \delta, \mathrm{ppm}\right): 7.33(\mathrm{~d}, 2 \mathrm{H}, J=13.9 \mathrm{~Hz}), 7.67$ (d, $\left.2 \mathrm{H}, J=13.9 \mathrm{~Hz}\right) .{ }^{13} \mathrm{C}-\mathrm{NMR}\left(\mathrm{DMSO}-d_{6}, \delta\right.$, ppm): $126.12(\mathrm{TeCH}), 133.70(\mathrm{CHCl})$.

\section{Conclusions}

Convenient methods for preparation of the previously unknown compounds 1-6, prospective precursors and synthons for organic synthesis, have been elaborated. The methods are efficient, simple and based on readily available starting materials (acetylene and tellurium tetrachloride). In contrast to the syn-addition of tellurium tetrachloride to substituted acetylenes [9-15] the reaction of tellurium tetrachloride with acetylene proceeds in a stereospecific manner via anti-addition to give the products 1 and 2 of $E$-stereochemistry (Schemes 2 and 3). This are the first examples of anti-additions of tellurium tetrachloride to acetylenic hydrocarbons. A mechanism involving the formation of the 3-membered intermediates $\mathbf{B}$ and $\mathbf{C}$ was proposed in order to explain the stereospecific anti-addition (Scheme 4). In the case of acetylene, the 3-membered intermediates ( $\mathbf{B}$ and $\mathbf{C}$, Scheme 4) are supposed to be energetically preferred in comparison with the 4-membered transition state $\mathbf{A}$ (Scheme 1).

\section{Acknowledgments}

Financial support of the Russian Academy of Sciences (Program 5.1.8) and the Russian Foundation for Basic Research (Grants No. 10-03-00543 and 11-03-00810) is gratefully acknowledged.

\section{References and Notes}

1. Schwarz, K.; Foltz, C.M. Selenium as an integral part of factor 3 against dietary necrotic liver degeneration. J. Am. Chem. Soc. 1957, 79, 3292-3293. 
2. Nogueira, C.W.; Zeni, G.; Rocha, J.B.T. Organoselenium and organotellurium compounds: Toxicology and pharmacology. Chem. Rev. 2004, 104, 6255-6286.

3. Tiekink, E.R.T. Therapeutic potential of selenium and tellurium compounds: Opportunities yet unrealized. Dalton Trans. 2012, 41, 6390-6395.

4. Wieslander, E.; Engman, L.; Svensjö, E.; Erlansson, M.; Johansson, U.; Linden, M.; Andersson, C.M.; Brattsand, R. Antioxidative properties of organotellurium compounds in cell systems. Biochem. Pharmacol. 1998, 55, 573-584.

5. Garberg, P.; Engman, L.; Tolmachev, V.; Lundqvist, H.; Gerdes, R.G.; Cotgreave, I.A. Binding of tellurium to hepatocellular selenoproteins during incubation with inorganic tellurite: Consequences for the activity of selenium-dependent glutathione peroxidase. Int. J. Biochem. Cell. Biol. 1999, 31, 291-301.

6. Sredni, B.; Caspi, R.R.; Klein, A.; Kalechman, Y.; Danziger, Y.; Ya'akov, M.B.; Tamari, T.; Shalit, F.; Albeck, M. A new immunomodulating compound (AS-101) with potential therapeutic application. Nature 1987, 330, 173-176.

7. Sredni, B.; Xu, R.H.; Albeck, M.; Gafter, U.; Gal, R.; Shani, A.; Tichler, T.; Shapira, J.; Bruderman, I.; Catane, R.; et al. The protective role of the immunomodulator AS101 against chemotherapy-induced alopecia: Studies on human and animal models. Int. J. Cancer 1996, 65, 97-103.

8. Sredni-Kenigsbuch, D.; Shohat, M.; Shohat, B.; Ben-Amitai, D.; Chan, C.C.; David, M. The novel tellurium immunomodulator AS101 inhibits interleukin-10 production and p38 MAPK expression in atopic dermatitis. J. Dermatol. Sci. 2008, 50, 232-235.

9. Petragnani, N.; Campos, M.M. Organic tellurium compounds. IV. Vinylic and ethynylic tellurium derivatives. Tetrahedron 1962, 18, 527-530.

10. Uemura, S.; Miyoshi, H.; Okano, M. Regio- and stereospecific Z-iodo- and Z-bromochlorination of alkylphenylacetylenes via Z-chlorotelluration. Chem. Lett. 1979, 1357-1358.

11. Chieffi, A.; Menezes, P.H.; Comasseto, J.V. Reduction of organotelluriun trichlorides with sodium borohydryde. Organometallics 1997, 16, 809-811.

12. Petragnani, N.; Mendes, S.R.; Silveira, C.C. Tellurium tetrachloride: An improved method of preparation. Tetrahedron Lett. 2008, 49, 2371-2372.

13. Cunha, R.L.O.R.; Zukerman-Schpector, J.; Caracelli, I.; Comasseto, J.V. Revisiting the addition reaction of $\mathrm{TeCl}_{4}$ to alkynes: The crystal structure and docking studies of 1-chloro-2trichlorotelluro-3-phenyl-propen-2-ol. J. Organometal. Chem. 2006, 691, 4807-4815.

14. Chauhan, A.K.S.; Bharti, S.N.; Srivastava, R.C.; Butcher, R.J.; Duthie, A. Stereospecific chlorotelluration of terminal acetylenes. J. Organomet. Chem. 2012, 708-709, 75-81.

15. Zukerman-Schpector, J.; Haiduc, I.; Dabdoub, M.J.; Biazzotto, J.C.; Braga, A.L.; Dornelles, L.; Caracelli, I. Dichloro-bis(2-chloro-2-phenyl-vinyl)Te(IV) and dibromo-bis(2-bromo-2-phenylvinyl)Te(IV): Supramolecular self-assembly through different $\pi$-aryl interactions. Z. Kristallogr. 2002, 217, 609-614.

16. Braverman, S.; Cherkinsky, M.; Jana, R.; Kalendar, Y.; Sprecher, M. Reaction of selenium and telluriun halides with propargyl alcohols. The regio- and stereoselectivity of addition to the triple bond. J. Phys. Org. Chem. 2010, 23, 1114-1120. 
17. Zeni, G.; Ludtke, D.S.; Panatieri, R.B.; Braga, A.L. Vinylic tellurides: From preparation to their applicability in organic synthesis. Chem. Rev. 2006, 106, 1032-1076.

18. Petragnani, N.; Stefani, H.A. Tellurium in Organic Synthesis; Academic Press: London, UK, 2007.

19. Petragnani, N.; Stefani, H.A. Advances in organic tellurium chemistry. Tetrahedron 2005, 61, 1613-1679.

20. Comasseto, J.V.; Stefani, H.A.; Chiefi, A.; Zukerman-Schpector, J. Addition of organotellurium trihalides to acetylenes. Organometallics 1991, 10, 845-846.

21. Potapov, V.A.; Amosova, S.V.; Khangurov, A.V.; Petrov, P.A. Synthesis of acetylenic tellurides by the iodomethane-induced reaction of dialkyl ditellurides with phenylacetylene. Phosphorus Sulfur Silicon Relat. Elem. 1993, 79, 273-275.

22. Potapov, V.A.; Amosova, S.V. New routes to unsaturated organoselenium and organotellurium compounds. Russ. J. Org. Chem. 1996, 32, 1099-1109.

23. Potapov, V.A.; Amosova, S.V.; Shestakova, V.Y.; Zhnikin, A.R.; Petrov, B.V. Synthesis of alkyl ethynyl tellurides and 1,2-bis(alkyltelluro) acetylenes by electrophilic-reagent-induced reaction of dialkyl ditellurides with acetylene. Rec. Trav. Chim. 1996, 115, 441-442.

24. Potapov, V.A.; Amosova, S.V.; Petrov, P.A. Aromatic substitution and dealkylation by alkanetellurolate anions. Tetrahedron Lett. 1992, 33, 6515-6518.

25. Potapov, V.A.; Amosova, S.V.; Shestakova, V.Y. Novel synthesis of unsaturated organoselenium and organotellurium compounds based on organic dichalcogenides and elemental chalcogens. Phosphorus Sulfur Silicon Relat. Elem. 1998, 136-138, 205-208.

26. Potapov, V.A.; Amosova, S.V.; Beletskaya, I.P.; Starkova, A.A.; Hevesi, L. Organic diselenides and ditellurides: Disproportionations, synthesis of stannyl selenides, reactions with acetylenes. Phosphorus Sulfur Silicon Relat. Elem. 1998, 136-138, 591-594.

27. Potapov, V.A.; Trofimov, B.A. 1-(Organosulfanyl)-, 1-(organoselanyl)-, and 1-(organotellanyl)alk-1ynes. Sci. Synth. 2005, 24, 957-1005.

28. Potapov, V.A.; Amosova, S.V. New methods for preparation of organoselenium and organotellurium compounds from elemental chalcogens. Russ. J. Org. Chem. 2003, 39, 1373-1380.

29. Potapov, V.A.; Musalov, M.V.; Amosova, S.V.; Musalova, M.V.; Penzik, M.V. Reaction of selenium dichloride with divinyl telluride. Russ. J. Org. Chem. 2011, 47, 950-951.

30. Musalov, M.V.; Potapov, V.A.; Amosova, S.V.; Musalova, M.V.; Volkova, K.A. Reactions of selenium dichloride and dibromide with diallyl telluride. Russ. J. Gen. Chem. 2011, 81, 2201-2202.

31. Trofimov, B.A.; Gusarova, N.K.; Tatarinova, A.A.; Potapov, V.A.; Sinegovskaya, L.M.; Amosova, S.V.; Voronkov, M.G. Alkyl vinyl tellurides from tellurium, acetylene and alkyl halides. Tetrahedron Lett. 1988, 44, 6739-6744.

32. Potapov, V.A.; Amosova, S.V. Synthesis of vinylic selenides and tellurides by the addition of alkaneselenolate and alkanetellurolate anions to acetylenes. Phosphorus Sulfur Silicon Relat. Elem. 1993, 79, 277-280.

33. Gusarova, N.K.; Trofimov, B.A.; Tatarinova, A.A.; Potapov, V.A.; Gusarov, A.V.; Amosova, S.V.; Voronkov, M.G. Reactions of chalcogenes with acetylene .4. Synthesis of divinyl telluride by the direct reaction of tellurium with acetylene. Zh. Org. Khim. 1989, 25, 39-45. 
34. Gusarova, N.K.; Trofimov, B.A.; Tatarinova, A.A.; Potapov, V.A.; Sinegovskaya, L.M.; Amosova, S.V.; Voronkov, M.G. Reactions of chalcogens with acetylene. 3. Alkyl vinyl tellurides from tellurium, acetylene and alkyl halides. Zh. Org. Khim. 1988, 24, 1869-1875.

35. Trofimov, B.A.; Gusarova, N.K.; Tatarinova, A.A.; Amosova, S.V.; Sinegovskaya, L.M.; Keiko, V.V.; Potapov, V.A. Vinyl methyl telluride. Zh. Org. Khim. 1984, 20, 1802-1802.

36. Potapov, V.A.; Gusarova, N.K.; Amosova, S.V.; Tatarinova, A.A.; Sinegovskaya, L.M.; Trofimov, B.A. Elementary tellurium reaction with phenylacetylene-Synthesis of 3-benzylidene4-phenyl-1,2-ditellurole and Z,Z-distyryltelluride. Zh. Org. Khim. 1986, 22, 220-221.

37. Potapov, V.A.; Amosova, S.V.; Kashik, A.S. Reactions of selenium and tellurium metals with phenylacetylene in 3-phase catalytic systems. Tetrahedron Lett. 1989, 30, 613-618.

38. Potapov, V.A.; Kashik, A.S.; Amosova, S.V. Reaction of metal tellurium with phenylacetylene under the phase-transfer catalysis. Zh. Org. Khim. 1988, 24, 2005-2006.

39. Amosova, S.V.; Martynov, A.V.; Shagun, V.A.; Musalov, M.V.; Larina, L.I.; Krivdin, L.B.; Zhilitskaya, L.V.; Voronkov, M.G. Anti-markovnikov addition of tellurium tetrachloride to trimethyl ethynyl silane. J. Organomet. Chem. 2008, 693, 2509-2513.

40. Amosova, S.V.; Martynov, A.V.; Penzik, M.V.; Makhaeva, N.A.; Potapov, V.A.; Albanov, A.I.; Zhilitskaya, L.V.; Voronkov, M.G. 4,4-Diorganyl-1,1,3,6-tetrachloro-1,4-tellura(IV)silafulvenesNew class of tellurium-silicon containing heterocycles. J. Organomet. Chem. 2008, 693, 3650-3654.

41. Trofimov, B.A.; Gusariva, N.K. Acetylene: New prospects of classical reactions. Russ. Chem. Rev. 2007, 76, 507-527.

42. Potapov, V.A.; Musalov, M.V.; Musalova, M.V.; Amosova, S.V. Reaction of tellurium tetrachloride with acetylene. Russ. Chem. Bull. 2009, 58, 2404-2405.

43. Shmid, G.H. Electrophilic Additions to Carbon-Carbon Triple Bonds. In The Chemistry of the Carbon-Carbon Triple Bond; Patai, S., Ed.; John Wiley \& Sons: Chichester, UK, 1978; p. 275.

44. Dabdoub, M.J.; Dabdoub, V.B.; Comasseto, J.V.; Petragnani, N. Synthesis of vinylic tellurides. J. Organomet. Chem. 1986, 308, 211-222.

45. Dabdoub, M.J.; Comasseto, J.V. Divinyl ditelluride: Synthesis and reactivity. J. Organomet. Chem. 1988, 344, 167-173.

46. Amosova, S.V.; Gostevskaya, V.I.; Gavrilova, G.M.; Potapov, V.A.; Kashik, A.S. Preparative synthesis of divinyl ditelluride. Zh. Org. Khim. 1988, 24, 454-455.

Sample Availability: Samples of compound $\mathbf{1}$ are available from the authors.

(C) 2012 by the authors; licensee MDPI, Basel, Switzerland. This article is an open access article distributed under the terms and conditions of the Creative Commons Attribution license (http://creativecommons.org/licenses/by/3.0/). 